\title{
高濃度石炭一水スラリーの流動性に対するアルコール ベース多鎖型高分子量非イオン界面活性剤の效果
}

\author{
中 昭廣・杉山浩・本荘秀一・杉山友男 \\ 第一工業製薬株式会社・石炭関運技術研究室 (京都市下京区西七条東久保町 55 番地)
}

\begin{abstract}
Effects of Alcohol Base Multi-Branched High Molecular Weight Nonionic Surface Active Agents on the Fluidity of Concentrated Coal-Water Slurry
\end{abstract}

\author{
Akihiro Naka, Hiroshi Sugiyama, Syuichi Honjo, and Tomoo Sugiyama \\ Dai-Ichi Kogyo Seiyaku Co., Ltd. (55, Nishi-Shichijo, Higashikubo-cho, Shimokyo-ku, Kyoto)
}

\begin{abstract}
A fuel of coal-water slurry (hereinafter simply called CWS) must be combustible in an as-pre= pared condition without previous dyhydration. For this purpose, it was necessary to increase the concentration of coal in CWS.

Thus, alcohol based multi-branched high molecular nonionic surface active agents were synthe= sized to evaluate their effects on the fluidity of CWS while measuring their physicochemical proper= ties. The results indicated the following.

1) For CWS of Tatung coal, the coal concentration could not be increased beyond $59 \%$ in the absence of a surface active agent.

2) Copolymers prepared by adding propylene oxide and ethylene oxide to glycerol, diglycerol or sorbitol showed excellent fluidity. That is, by these agents, Tatung coal CWS was made having a viscosity of $1,300 \mathrm{cP}$ at a coal concentration of $71 \%$.

3) Among the above copolymers, a multi-branched high molecular nonionic surface active agent, whose side chain had a molecular weight of 10,000 or more and an ethylene oxide content between 85 and $95 \%$, improved the fluidity of CWS most effectively.
\end{abstract}

\section{1 緒言}

近年，石油資源の枯渴が心配される中にあって，埋藏 量が石油の 10 倍以上もある石炭資源が再度見直されつ つ㟧り，石炭利用抬大技術の研究がさかんに実施される ようになってきた。なかでも，石炭が固体 (粉体) であ ることによる久点，すなわち流体輸送ができないこと， 粉じんが立ちやすいこと, 自然発火しやすいこと等を改 善するために石炭の流体化に着目し, CWS (Coal Water Slurry）燃料の研究が各国で実施されている。

CWS 燃料は, オイルレス然料で石油代替燃料として の価值が高く期待できる。しかしこの種の燃料はいまだ に実用化されておらず，米国ブラックメサでは石炭濃度 が約 50\% と低いCWS の翰送がなされているにすぎな い。この CWS は，パイプラインで輸送後やっかいな脱 水をした後燃焼に供されており, この脱水と水処理の欠
点からこの種の低濃度 CWS は広く普及しなかった。こ れら工程を必要としない CWS 燃料, 寸なわ方石炭濃度 が $65 \%$ 程度以上の高濃度 CWS 泣, 直接燃燒できる利 点に加えて, 輸送費や貯蔵費を低減できるので近年世界 で注目されている。

粉炭と水を混合しただ讨では，粉炭が水中でゲル化し 高濃度スラリーができないため，ゲル化を防止し石炭粒 子を分散できる薬剤が不可久であり，この種の研究さ若

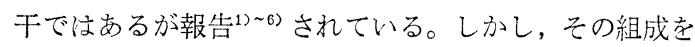
開示したものは少なく，たとえ組成開示されたものも， ナフタレンスルホン酸ナトリウムホルマリン縮合物やリ グニンスルホン酸ナトリウム塩など古くから他の分散分 野で使われていたものを利用した例多多い。これらの薬 剤を用いたスラリーの流動性は, 後述する結果のとお り，石炭濃度 $65 \%$ 程度の CWS をつくるのが限界であ り, 充分満足される性能で沈な上に, ナトリウムを含 
むため燃焼時灰の融点を下げボイラー腐食を起こすの゙ 点があった。

そこで著者らは，原料が㤘素，水素，酸素からなり， 前記欠点を持たない非イオン界面活性剤に着目し，その 流動性向上効果を研究した。本報告では，一般的な脂肪 族アルコール系非イオン界面活性㓮以外に，多価アルコ ールを出発物質としてこれにアルキレンオキシドを付 加した多鎖型高分子量非イオン界面活性剤を合成し，そ れらの CWS の流動性に対する効果を比較した。その結 果多鎖型高分子量非イオン界面活性剤の性能が優れ, 分 子の鎖長やエチレンオキシド含有率を好ましい範囲にす れば，石炭濃度 $70 \%$ 以上の CWS をつくることができ た。その詳細を以下に報告する。

\section{2 実験}

\section{$2 \cdot 1$ 界面活性剂}

$2 \cdot 1 \cdot 1$ 低分子量非イオン界面活性剤

ドデシル=ポリオキシエチレン=エーテル（以下 LAE $\mathrm{O}_{x}$ と略す）とオレイル=ポリオキシエチレン=エーテル (以下 $\mathrm{OAEO}_{x}$ と略す) は第一工業製薬（株）製，ノイ ゲン ET シリーズを用いた。

$2 \cdot 1 \cdot 2$ 陰イオン性分散剂

ナフタレンスルホン酸ナトリウムホルマリン縮合物は 第一工業製薬 (株) 製を，リグニンスルホン酸ナトリウ ムは山陽国策パルプ（株）品を使用した。

2・1・3 アルコールベース多鎖型非イオン界面活性剤 1)原料

グリセリン (以下 Gl と略す)，ジグリセリン (DiGl) 及びソルビトール（So）は試薬一級を用いた。またエチ レンオキシド (EO) は三菱油化 (株) 製のものを, プロ ピレンオキシド (PO) は旭ガラス (株) 製のものを用い た。

\section{2) 合成方法}

耐圧ステンレス容器に出発原料を仕込み, その後触媒 として対最終製品当たり $0.1 \%$ の $\mathrm{KOH}$ を入れ減圧下 で加熱脱水した後, $\mathrm{PO}$ は $115 \pm 5^{\circ} \mathrm{C}, 2 \sim 2.5 \mathrm{~atm}$ で, EO は $120 \pm 5^{\circ} \mathrm{C}, 1.0 \sim 1.5 \mathrm{~atm}$ で 15〜24 h かくはん して反応し，目的の界面活性剂を合成した。

3）平均分子量の測定

合成した界面活性剤のヒドロキシル価 (OHV) を測 定して分子量を求め, これに出発物質の活性水素数を乗
じて，平均分子量を求めた。

4) 量り点の測定

$5 \% \mathrm{~K}_{2} \mathrm{SO}_{4}$ 水溶液中に界面活性剤を $1 \%$ になるよう に溶解した液をつくり，常法により肉眼判定した。

5）表面張力の測定

$0.1 \%$ の界面活性剤水溶液をつくり，20 2 において トラウベ法で測定した。

\section{$2 \cdot 2$ 石炭とその粉砕}

\section{$2 \cdot 2 \cdot 1$ 石 炭}

石炭良青崖の 1 種である大同炭 (中国産)を用いた。 この石炭の分析值を Table-1 に示市。

\section{$2 \cdot 2 \cdot 2$ 石炭の粉砕}

まず，塊状の石炭をハンマーミル $\mathrm{H}-12$ 型（細川ミク ロン社製) で $5 \mathrm{~mm}$ 以下に粗砕した後, ステンレスボー ルミル (内容量 $7 l$, ボールは直径 $32 \mathrm{~mm}$ のものを 50 \%充てん）を用いて，200丮通過量が $73 \%$ になるよう に粉砕した。

\subsection{CWS の調製}

$2 \cdot 3 \cdot 1$ 調製方法と最高石炭濃度測定方法

ビーカー $(200 \mathrm{ml})$ に所定量の蒸留水と界面活性剤を 精ひょうし，よく混合した後 3 枚羽根を有するプロペラ を用い $800 \mathrm{rpm}$ のかくはんを加えながら，最初は粉炭を $1 \mathrm{~g}$ ずつ, 終盤は $0.1 \mathrm{~g}$ ずつ加え充分混合する。ビー カーを 45 度まで傾けスラリーが流動しない時点を終点 とし，この一歩手前の石炭濃度を測定し，この值を一定 条件下にお汀る最高石炭濃度 $(\mathrm{MxCC})$ と規定した。

$2 \cdot 3 \cdot 2$ 石炭濃度測定方法

スラリーを $105^{\circ} \mathrm{C}$ で $2 \mathrm{~h}$ 乾燥して非揮発分量をもと め, これより界面活性昘量を差し引き石炭濃度を求为 た。

$2 \cdot 3 \cdot 3$ CWS の粘度測定

ブルックフィールド型粘度計を用い, No. 3 ローター を $60 \mathrm{rpm}$ で $1 \mathrm{~min}$ 回転させ, $25^{\circ} \mathrm{C}$ で粘度を測定した。

\section{3 結果と考察}

\section{$3 \cdot 1$ 界面活性剂の曇り点と表面張力}

$3 \cdot 1 \cdot 1$ 脂肪族アルコール采非イオン界面活性剤の物 性

Table-2 にはドデシルアルコール EO 付加物とオレ イルアルコール $\mathrm{EO}$ 付加物の量り点と表面張力を示す。 本表よりドデシルアルコール EO 付加物の樘り点は

Table-1 Analysis of the Tatung coal.

\begin{tabular}{|c|c|c|c|c|c|c|c|c|c|c|}
\hline \multirow[b]{2}{*}{ Sample } & \multicolumn{4}{|c|}{ Approximate analysis } & \multirow{2}{*}{$\begin{array}{l}\text { Cal. value } \\
\text { (kcal/kg) }\end{array}$} & \multicolumn{5}{|c|}{ Ultimate analysis } \\
\hline & $\begin{array}{l}\text { Inherent } \\
\text { moisture }\end{array}$ & Ash & $\begin{array}{l}\text { Volatile } \\
\text { material }\end{array}$ & $\begin{array}{c}\text { Fixed } \\
\text { carbon }\end{array}$ & & $\mathrm{C}$ & $\mathrm{H}$ & $\mathrm{O}$ & N & S \\
\hline $\begin{array}{c}\text { Tatung } \\
\text { coal }\end{array}$ & 4.1 & 10.3 & 30.5 & 57.0 & 7,240 & 84.3 & 4.8 & 9.4 & 0.9 & 0.6 \\
\hline
\end{tabular}


Table-2 Properties of polyoxyethylene fatty alcohol ethers.

\begin{tabular}{|c|c|c|}
\hline Surfactants & $\begin{array}{c}\text { Cloud point } \\
\left({ }^{\circ} \mathrm{C}\right)\end{array}$ & $\begin{array}{l}\text { Surface tension } \\
\quad(\text { dyn } / \mathrm{cm})\end{array}$ \\
\hline$*_{1} \mathrm{LA} \mathrm{EO}_{2}$ & $<5.0$ & - \\
\hline LA $\mathrm{EO}_{4}$ & $<5.0$ & 26.1 \\
\hline LA $\mathrm{EO}_{6}$ & 52.1 & 27.0 \\
\hline $\mathrm{LA} \mathrm{EO}_{3}$ & 54.8 & 27.6 \\
\hline $\mathrm{LA} E \mathrm{EO}_{10}$ & 61.0 & 31.3 \\
\hline LA $E_{12}$ & 68.1 & 35.0 \\
\hline LA $\mathrm{EO}_{14}$ & 76.7 & 36.2 \\
\hline LA $\mathrm{EO}_{16}$ & 81.0 & 37.7 \\
\hline LA $E_{18}$ & 83.1 & 39.4 \\
\hline LA EO $\mathrm{EO}_{20}$ & 84.6 & 41.5 \\
\hline$*_{2} \mathrm{OA}_{\mathrm{EO}}$ & $<5.0$ & - \\
\hline $\mathrm{OA} \mathrm{EO}_{4}$ & $<5.0$ & 58.3 \\
\hline $\mathrm{OA} \mathrm{EO}_{\hat{6}}$ & $<5.0$ & 40.9 \\
\hline $\mathrm{OA} \mathrm{E \textrm {E } _ { 8 }}$ & 45.1 & 39.1 \\
\hline $\mathrm{OA} \mathrm{EO}_{10}$ & 54.5 & 39.1 \\
\hline $\mathrm{OA} \mathrm{EO}_{12}$ & 63.6 & 39.2 \\
\hline $\mathrm{OA} \mathrm{E \textrm {EO } _ { 1 4 }}$ & 67.6 & 39.2 \\
\hline $\mathrm{OA} \mathrm{EO}_{16}$ & 72.8 & 40.0 \\
\hline $\mathrm{OA} \mathrm{EO}_{18}$ & 75.0 & 40.2 \\
\hline $\mathrm{OA} \mathrm{EO}_{20}$ & 77.1 & 44.8 \\
\hline
\end{tabular}

Note : *1 Dodecyl alcohol

*2 Oleyl alcohol

Cloud point : $1 \%$ surfactant in $5 \% \mathrm{~K}_{2} \mathrm{SO}_{4}$ aqueous solution

Surface tension : $0.1 \%$ surfactant solution at $20^{\circ} \mathrm{C}$ by Traube method

$84.6^{\circ} \mathrm{C}$ 以下であり, 表面張力は $26.1 \sim 41.5 \mathrm{dyn} / \mathrm{cm}$ で, オレイルアルコール $\mathrm{EO}$ 付加物 の量り点は $77.1^{\circ} \mathrm{C}$ 以 下であり表面張力汶 $39.1 \sim 58.3 \mathrm{dyn} / \mathrm{cm}$ であった。

$3 \cdot 1 \cdot 2$ アルコールベース多鎖型高分子量悲イオン界 面活性剤の物性

アルコールベース多鎖型高分子量非イオン界面活性剂 を 53 種類合成し，それらの暑り点と表面張力を測定 した。Table-3 にはグリセリンベースの EO 付加物と $\mathrm{PO} \cdot \mathrm{EO}$ 付加物の物性を示寸が, $\mathrm{EO}$ 付加物の曇り点は $73.8^{\circ} \mathrm{C}$ 以上で表面張力は $63.0 \sim 65.4 \mathrm{dyn} / \mathrm{cm}$ であり, $\mathrm{PO} \cdot \mathrm{EO}$ 付加物の暴り点は $72.6^{\circ} \mathrm{C}$ 以下で表面張力は 35.8 62.1 dyn $/ \mathrm{cm}$ であった。Table-4 にはジグリセ リンベースの $\mathrm{EO}$ 付加物と $\mathrm{PO} \cdot \mathrm{EO}$ 付加物の物性を示 すがグリセリンベースのものとよく似ていることがわか った。また Table-5 にはソルビトールベースの EO 付 加体と $\mathrm{PO} \cdot \mathrm{EO}$ 付加体の物性を示すが, この結果も Table-3 や Table-4 とよく似ており，いずれも表面 張力低下能がやや劣ることがわかった。

\section{2 低分子量非イオン界面活性剤の流動性向上効果}

まず界面活性剤を用いずに大同炭の CWS をつくり， $\mathrm{MxCC}$ を測定した。スラリーの $\mathrm{MxCC}$ 值は $58.6 \%$ で
Table-3 Properties of glycerol based multi-branched high molecular weight nonionic surface active agents.

\begin{tabular}{l|c|c}
\hline Surfactants & $\begin{array}{c}\text { Cloud point } \\
\left({ }^{\circ} \mathrm{C}\right)\end{array}$ & $\begin{array}{c}\text { Surface tension } \\
(\text { dyn/cm })\end{array}$ \\
\hline $\mathrm{Gl} * \mathrm{EO}_{90}$ & $>95.0$ & 65.4 \\
$\mathrm{Gl} \mathrm{EO} \mathrm{EO}_{300}$ & 87.7 & 63.9 \\
$\mathrm{Gl} \mathrm{EO}_{600}$ & 87.7 & 63.9 \\
$\mathrm{Gl} \mathrm{EO}_{900}$ & 73.8 & 63.0 \\
\hline $\mathrm{Gl} \mathrm{PO}_{60} \mathrm{EO}_{180}$ & 72.6 & 52.2 \\
$\mathrm{Gl} \mathrm{PO}_{60} \mathrm{EO}_{500}$ & 70.9 & 58.7 \\
$\mathrm{Gl} \mathrm{PO}_{60} \mathrm{EO}_{600}$ & 65.9 & 61.2 \\
$\mathrm{Gl} \mathrm{PO}_{60} \mathrm{EO}_{900}$ & 63.4 & 62.1 \\
\hline $\mathrm{Gl} \mathrm{PO}_{120} \mathrm{EO}_{90}$ & 65.0 & 35.8 \\
$\mathrm{Gl} \mathrm{PO}_{120} \mathrm{EO}_{180}$ & 65.7 & 40.8 \\
$\mathrm{Gl} \mathrm{PO}_{120} \mathrm{EO}_{300}$ & 70.6 & 52.0 \\
$\mathrm{Gl} \mathrm{PO}_{120} \mathrm{EO}_{450}$ & 68.6 & 59.0 \\
$\mathrm{Gl} \mathrm{PO}_{120} \mathrm{EO}_{600}$ & 66.9 & 59.8 \\
\hline $\mathrm{Gl} \mathrm{PO}_{180} \mathrm{EO}_{90}$ & $<5.0$ & 37.6 \\
$\mathrm{Gl} \mathrm{PO}_{180} \mathrm{EO}_{180}$ & 41.2 & 37.5 \\
$\mathrm{Gl} \mathrm{PO}_{180} \mathrm{EO}_{300}$ & 63.6 & 38.0 \\
$\mathrm{Gl} \mathrm{PO}_{180} \mathrm{EO}_{450}$ & 64.6 & 41.4 \\
\hline
\end{tabular}

Note: * Glycerol

Cloud point $: 1 \%$ surfactant in $5 \% \mathrm{~K}_{2} \mathrm{SO}_{4}$ aqueous solution

Surface tension : $0.1 \%$ surfactant solution at $20^{\circ} \mathrm{C}$ by Traube method

あり，添加剤を用いなければ目標の $65 \%$ 好ましくは 70 \% 以上の高濃度 CWS をつくることができなかった。 次に一般的な低分子量非イオン界面活性剤の代表例とし て, $\mathrm{EO}$ 付加モル数の異なるドデシルアルコール $\mathrm{EO}$ 付 加物と, オレイルアルコール $\mathrm{EO}$ 付加物を対石炭 $0.4 \%$ 加えて CWS をつくり，MxCC 值を測定した。結果を Fig. -1 に示す。

この種の界面活性剤の $\mathrm{MxCC}$ 值は 54.7 61.3\% で あり界面活性剤を加えない場合とほとんど同じであっ

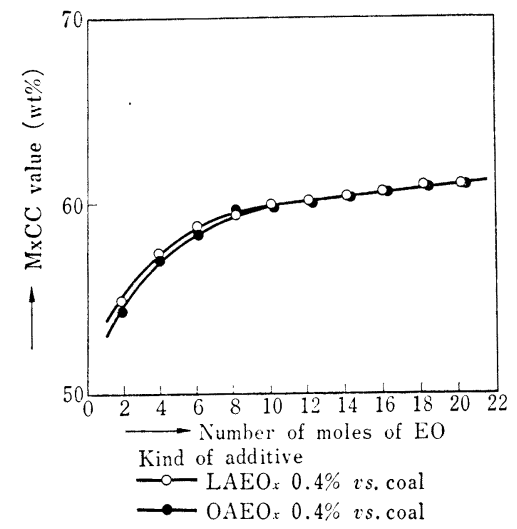

Fig.-1 Effects of polyoxyethylene fatty alcohol ethers on $\mathrm{MxCC}$ value of $\mathrm{CWS}$. 
Table-4 Properties of diglycerol based multibranched high molecular weight nonionic surface active agents.

\begin{tabular}{l|c|c}
\hline \multicolumn{1}{c|}{ Surfactants } & $\begin{array}{c}\text { Cloud point } \\
\left({ }^{\circ} \mathrm{C}\right)\end{array}$ & $\begin{array}{c}\text { Surface tension } \\
(\text { dyn/cm })\end{array}$ \\
\hline Digl*EO $\mathrm{EO}_{120}$ & $>95.0$ & 64.4 \\
Digl $\mathrm{EO}_{400}$ & 81.8 & 63.0 \\
Digl $\mathrm{EO}_{300}$ & 73.2 & 63.0 \\
Digl $\mathrm{EO}_{1200}$ & 68.7 & 62.6 \\
\hline Digl $\mathrm{PO}_{80} \mathrm{EO}_{240}$ & 73.7 & 52.3 \\
Digl $\mathrm{PO}_{80} \mathrm{EO}_{400}$ & 71.7 & 59.1 \\
Digl $\mathrm{PO}_{80} \mathrm{EO}_{800}$ & 61.2 & 60.4 \\
Digl $\mathrm{PO}_{80} \mathrm{EO}_{1200}$ & 63.9 & 61.7 \\
\hline Digl $\mathrm{PO}_{160} \mathrm{EO}_{120}$ & $<5.0$ & 35.5 \\
Digl $\mathrm{PO}_{160} \mathrm{EO}_{240}$ & 65.0 & 41.2 \\
Digl $\mathrm{PO}_{160} \mathrm{EO}_{400}$ & 65.2 & 50.2 \\
Digl $\mathrm{PO}_{160} \mathrm{EO}_{600}$ & 69.6 & 56.5 \\
Digl $\mathrm{PO}_{160} \mathrm{EO}_{800}$ & 67.6 & 57.4 \\
\hline Digl $\mathrm{PO}_{240} \mathrm{EO}_{120}$ & $<5.0$ & 38.5 \\
Digl $\mathrm{PO}_{240} \mathrm{EO}_{240}$ & 61.4 & 40.1 \\
Digl $\mathrm{PO}_{240} \mathrm{EO}_{400}$ & 65.7 & 44.5 \\
Digl $\mathrm{PO}_{240} \mathrm{EO}_{600}$ & 68.0 & 53.2 \\
Digl $\mathrm{PO}_{240} \mathrm{EO}_{800}$ & 66.6 & 56.7 \\
\hline
\end{tabular}

\section{Note : * Diglycerol}

Cloud point $: 1 \%$ surfactant in $5 \% \mathrm{~K}_{2} \mathrm{SO}_{4}$ aqueous solution

Surface tension : $0.1 \%$ surfactant solution at $20^{\circ} \mathrm{C}$ by Traube method

た。EO 付加モル数の小さいものは, 薬剤無添加時に比 ベて逆に $\mathrm{MxCC}$ 值が小さくなり, $\mathrm{EO}$ 付加モル数の増 加にともなって大きくなる傾向があった。

\section{3 アルコールベース多鎖型高分子量非イオン界面 活性剂の流動性向上効果}

$3 \cdot 1 \cdot 2$ 項で合成した 53 種類のアルコールベース多 鎖型高分子量非イオン界面活性剤を対石炭 $0.4 \%$ 添加 して, 大同炭を用いた CWS をつくり， MxCC を測定 した。

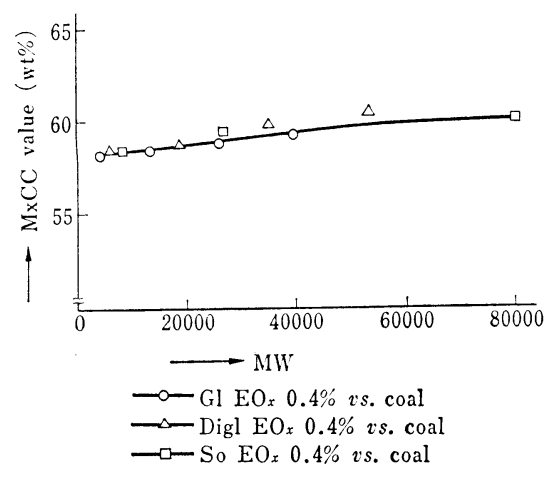

Fig.-2 Effects of polyoxyethylene alcohol ethers on $\mathrm{MxCC}$ value of CWS.
Table-5 Properties of sorbitol based multibranched high molecular weight nonionic surface active agents.

\begin{tabular}{l|c|c}
\hline \multicolumn{1}{c|}{ Surfactant } & $\begin{array}{c}\text { Cloud point } \\
\left({ }^{\circ} \mathrm{C}\right)\end{array}$ & $\begin{array}{c}\text { Surface tension } \\
(\text { dyn } / \mathrm{cm})\end{array}$ \\
\hline So*EO $\mathrm{EO}_{180}$ & $>95.0$ & 62.9 \\
So $\mathrm{EO}_{600}$ & 78.5 & 62.5 \\
So $\mathrm{EO}_{1200}$ & 70.1 & 61.6 \\
So $\mathrm{EO}_{1800}$ & 68.3 & 62.1 \\
\hline So $\mathrm{PO}_{120} \mathrm{EO}_{360}$ & 74.8 & 56.4 \\
So $\mathrm{PO}_{120} \mathrm{EO}_{600}$ & 70.6 & 61.2 \\
So $\mathrm{PO}_{120} \mathrm{EO}_{1200}$ & 64.8 & 61.7 \\
So $\mathrm{PO}_{120} \mathrm{EO}_{1800}$ & 62.5 & 61.7 \\
\hline So $\mathrm{PO}_{240} \mathrm{EO}_{180}$ & 57.0 & 39.7 \\
So $\mathrm{PO}_{240} \mathrm{EO}_{360}$ & 65.1 & 46.4 \\
So $\mathrm{PO}_{240} \mathrm{EO}_{600}$ & 71.0 & 56.3 \\
So $\mathrm{PO}_{200} \mathrm{EO}_{900}$ & 68.5 & 57.3 \\
So $\mathrm{PO}_{240} \mathrm{EO}_{1200}$ & 66.1 & 59.4 \\
\hline So $\mathrm{PO}_{360} \mathrm{EO}_{180}$ & $<5.0$ & 40.4 \\
So $\mathrm{PO}_{360} \mathrm{EO}_{360}$ & 53.9 & 44.1 \\
So $\mathrm{PO}_{360} \mathrm{EO}_{600}$ & 64.8 & 45.2 \\
So $\mathrm{PO}_{360} \mathrm{EO}_{900}$ & 69.2 & 51.9 \\
So $\mathrm{PO}_{360} \mathrm{EO}_{1200}$ & 66.3 & 52.6 \\
\hline
\end{tabular}

Note : * Sorbitol

Cloud point $: 1 \%$ surfactant in $5 \% \mathrm{~K}_{2} \mathrm{SO}_{4}$ aqueous solution

Surface tension : $0.1 \%$ surfactant solution at $20^{\circ} \mathrm{C}$ by Traube method

Fig.-2 はグリセリン，ジグリセリンまたはソルビト ールの $\mathrm{EO}$ 付加物について, 全分子量と MxCC 值の 関係を示す。

この図より, これらの構造の $\mathrm{EO}$ 付加物の $\mathrm{MxCC}$ 值 は 58.2〜 60.4\% であり, CWS の石炭濃度を高める効 果注弱いが, 分子量が大きくなるとわずかではあるが $\mathrm{MxCC}$ 值は大きくなる傾向にある。

次にグリセリン, ジグリセリンあるいはソルビトール

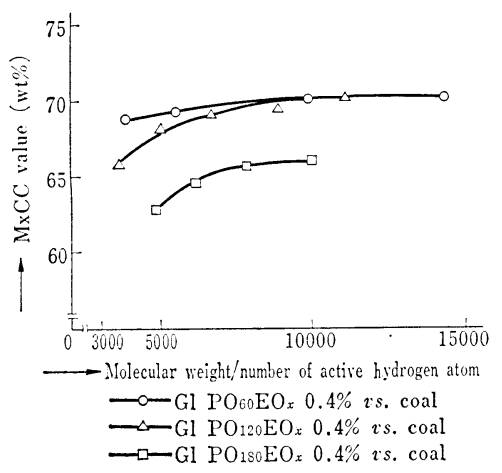

Fig.-3 Effects of polyoxyethylene-polyoxy= propylene glycerol ethers on $\mathrm{MxCC}$ value of CWS. 
の $\mathrm{PO} \cdot \mathrm{EO}$ 付加物 の $\mathrm{CWS}$ の 石炭濃度を高好効果について 検討した。分子の立体性と効果 の関倸を考察する意味から，鎖 長と関係する 1 活性水素当たり のアルキレンオキシドの分子量 を横軸に, MxCC 值を縦軸に した。

Fig.-3 はグリセリンの PO. $\mathrm{EO}$ 付加物について，1活性水 素当たりの分子量と $\mathrm{MxCC}$ 值 の関係を示す。

本困より，グリセリン PO・ $\mathrm{EO}$ 付加物は CWS の石炭濃度 を高めることができ, 最高のも ので $\mathrm{MxCC}$ 值は 70\% であっ た。1 活性水素当たりの分子量 の増加にともなって $\mathrm{MxCC}$ 值 が大きくなる傾向があり， 10,000 程度で最高值を示すこ とがわかった。また PO 付加 モル数は $120 \mathrm{~mol}$ 好ましくは $60 \mathrm{~mol}$ 以下が適しており, PO 付加モル数が大きくなりすぎる と $\mathrm{MxCC}$ が小さくなり高濃度 CWS をつくることができなか った。以上より, 分子は 10,000 程度の分子量の側鎖を持ち, PO 付加モル数を $120 \mathrm{~mol}$ 好ま しくは $60 \mathrm{~mol}$ 以下にし,さら に $\mathrm{EO}$ 付加モル数を $300 \mathrm{~mol}$ 以上にしたものが好ましいこと がわかった。

Fig.-4 はジグリセリンの $\mathrm{PO} \cdot \mathrm{EO}$ 付加物について, 1 活性 水素当たりの分子量と $\mathrm{MxCC}$ 值の関係を示す。

本図より，ジグリセリンベー スのものも CWS の石炭濃度を 高めることができ, PO 付加モ 儿数は $160 \mathrm{~mol}$ 好ましくは 80 $\mathrm{mol}$ 以下にし, さらに EO 付 加モル数を $400 \mathrm{~mol}$ 以上にし， 側鎖の分子量を 10,000 程度に なるように付加共重合すれば， $\mathrm{MxCC}$ 值が $70 \%$ になること がわかった。

Fig.-5 は, ソルビトールの

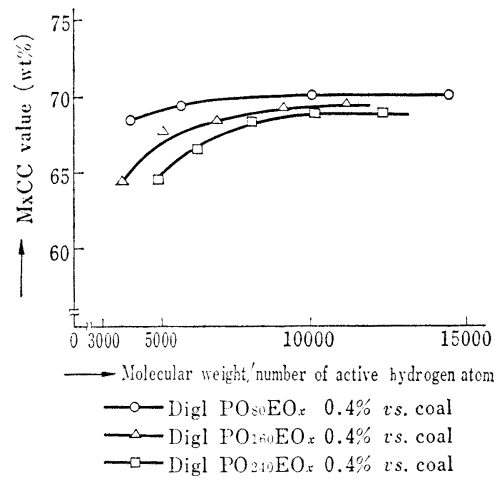

Fig.-4 Effects of polyoxyethylenepolyoxypropylene diglyce= rol ethers on $\mathrm{MxCC}$ value of CWS.

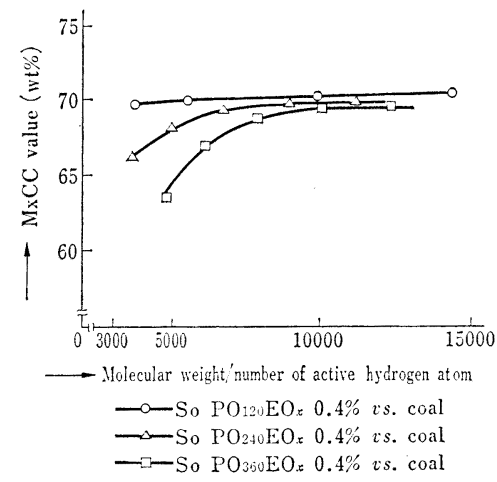

Fig.-5 Effects of polyoxyethylenepolyoxypropylene sorbitol ethers on $\mathrm{MxCC}$ value of CWS.

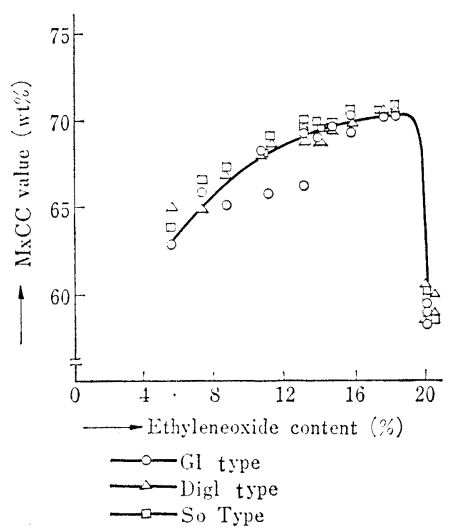

Fig.-6 Relation between $\mathrm{MxCC}$ value and ethyleneoxide contents of alcohol based high molecular weight nonionic surface active agents with multiple branching.

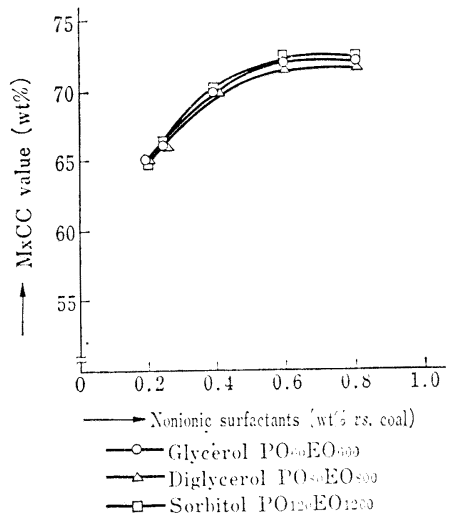

Fig.-7 Relation between amounts of additives and $\mathrm{MxCC}$ values of CWS consists of Tatung coal and polyoxyethylenepolyoxypropylene alcohol ether.

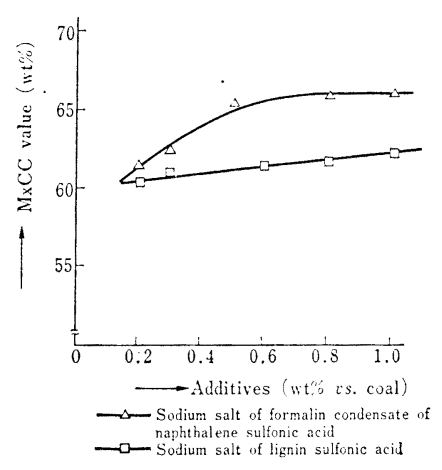

Fig.-8 Relation between amounts of additives and $\mathrm{MxCC}$ value of Tatung coal CWS using anionic dispersants.

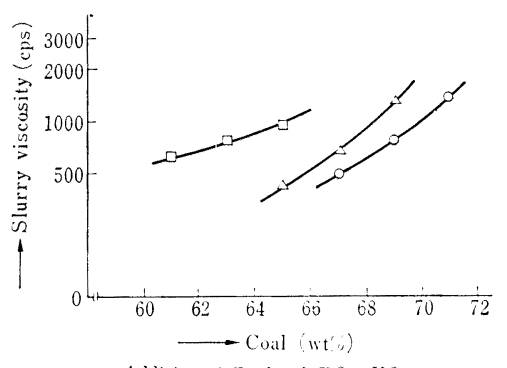

Additives : Sorbitol $\mathrm{PO}_{12} \mathrm{EO}_{12 \mathrm{w}}$

$\square-0.2 \%$ is. coal

$\longrightarrow 0.4 \%$ is. coal

$\longrightarrow-1.0 \%$ is. coal

Fig.-9 Relation between the concen= tration of the Tatung coal and viscosity of CWS using Sorbitol $\mathrm{PO}_{120} \mathrm{EO}_{1200}$. 
$\mathrm{PO} \cdot \mathrm{EO}$ 付加体について，1 活性水素当たりの分子量と $\mathrm{MxCC}$ 值の関倸を示す。

本図よりソルビトールの $\mathrm{PO} \cdot \mathrm{EO}$ 付加体 も $\mathrm{MxCC}$ 值 $70.3 \%$ を示し, 活性水素 1 こ当たりの分子量すなわ ち側鎖の分子量を 10,000 程度にすれば CWS の石炭濃 度を最も高的ることができることがわかった。

すなわち，CWS の石炭濃度を高めることができるア ルコールベース多鎖型高分子量非イオン界面活性剂依, 適切な $\mathrm{PO} \cdot \mathrm{EO}$ 比を保ち, 側鎖の分子量を 10,000 程度 に大きくする必要があり, 出発物質すなわちグリセリ ン, ジグリセリン, ソルビトールはいずれでもよいこと がわかった。次に, 適切な PO と EO の比を求めるた め $\mathrm{EO}$ 含有率と $\mathrm{MxCC}$ 值の関係を求め Fig.-6 に示 した。

本図より好ましい EO 含有率は 80〜95\% であり， 100\% になると CWS の石炭濃度を高める効果が著しく 低くなる。すなわち, 薬剤が石炭表面に吸着して立体障 害効果を発揮するためにはある程度の踈水性が必要と考 えられる。

アルコールベース多鎖型高分子量非イオン界面活性剂 汸，一般的な低分子量非イオン界面活性剂に比べて表面 張力低下能泣低いが，側鎖が多くかつ大きいため分子が 立体性に富み，石炭粒子を保護し粒子の動きを自由にす るため CWS の粘度が低下し石炭濃度を高くすることが できたと思われる。

\section{4 添加剂量と $\mathrm{MxCC}$}

$3 \cdot 3$ 項より, アルコールベース多鎖型高分子量非イオ ン界面活性剤の中で優れた効果が得られている 3 種類を 選定し, 添加剤量と $\mathrm{MxCC}$ の関係を検討した。その結 果を Fig.-7 に示す。また, 周知の分散剤であるナフタ レンスルホン酸ナトリウムホルマリン縮合物とリグニン スルホン酸ナトリウムの添加剤量と $\mathrm{MxCC}$ 值の関係を

Fig.-8 に示す。

Fig.-7 と Fig.-8 より添加剤の必要添加量は, 種類 にかかわりなく対石炭約 $0.6 \%$ であり，これ以下の場 合は $\mathrm{MxCC}$ が低下し，これ以上では $\mathrm{MxCC}$ はわずか に上昇するがほぼ一定になる。また，アルコールベース 多鎖型高分子量非イオン界面活性剤の $\mathrm{MxCC}$ の最高值 は 72.5\%であり，MxCC 值が 62〜67\% であるアニオ ン性分散剤より効果が優れている。

\section{5 添加剤量亡 CWS の粘度}

$\mathrm{MxCC}$ 值が最も高いソルビトール $\mathrm{PO}_{120} \mathrm{EO}_{1200}$ を用 いてその添加量と大同炭の濃度を種々かえた CWS をつ くりその粘度を測定した。得た結果を Fig.-9 亿示す。 その結果, ソルビトール $\mathrm{PO}_{120} \mathrm{EO}_{1200}$ を用いた場合, 石 炭濃度 $71 \%$ で $1300 \mathrm{cP}$ の流動性の良い大同炭 CWS をつくることができた。また添加量を $0.4 \%$ にした場 合, 石炭濃度 $69 \%$ で粘度 $1140 \mathrm{cP}$ のスラリーができ ることがわかった。

\section{4 結 論}

アルコールベース多鎖型高分子量非イオン界面活性凨 を合成し，大同炭を用いた CWS の流動性を保持しなが ら石炭濃度を高める効果を評価し次の結論を得た。

1）薬剂を用いない大同炭の CWS 注, 石炭濃度を 59 \% 以上にすることができないが, グリセリン，ジグリセ リンまたはソルビトールにプロピレンオキシドとエチレ ンオキシドを共重合したものは，石炭㳻度 $71 \%$ で粘度 $1300 \mathrm{cP}$ の流動性のよい CWS をつくることができた。

2) プロピレンオキシドとエチレンオキシドを付加 共重合し，側鎖すなわち 1 活性水素当たりの分子量を 10,000 以上にすることが好ましい。

3）エチレンオキシドの好ましい含有量の範囲は， 80 〜95\% の範囲である。

本研究の実施に当たり, 破究指導をしていただいた大阮大学 工学部教授阿河利男博士 並びに研究発表の機会をいただいた第 一工業製薬（株）の三浦隆彦氏に深謝いたします。 (昭和 59 年 9 月 17 日受理)

\section{文献}

1) C.A. Shook, S. Nurkowski, The Canada Journal of Chemical Eng., 55, 9 (1975)

2) R.S. Sheffee, First International Symposium on COM Combution, May, 1978 (Florida, U.S.A)

3) R.D. Glenn, A.W. Rhodes, EPRI Research Project FP-1164, 1180-4

4) R.S. Sheffee, E.T. Mchale, Second International Sym= posium on COM Combution, Nov. 1979 (Danvers, U.S.A)

5) R.S. Sheffee, R.L. Rowell, Third International Sym= posium on COM Combution, April 1981 (Florida, U. S.A)

6) R.K. Manfred, R.W. Borio, S.J. Vecci, For Presen= tation at the American Power Conference, April 18 20, 1983 (Chicago, U.S.A) 